\title{
LATERIZATION PROCESS OF PERIDOTITES IN SIRUKA, CHOISEUL, SOLOMON ISLANDS
}

\author{
Christopher V. Sagapoa*1, Akira Imai ${ }^{2}$, Takeyuki Ogata ${ }^{3}$, Kotaro Yonezu $^{1}$, and Koichiro \\ Watanabe ${ }^{1}$ \\ ${ }^{1}$ Department of Earth Resource Engineering, Faculty of Engineering, Kyushu University, Japan \\ ${ }^{2}$ Department of Earth Science and Technology, Faculty of Engineering and Resource Science, Akita University, Japan \\ ${ }^{3}$ International Center for Research and Education on Mineral and Energy Resources, Akita University, Japan
}

\begin{abstract}
The lateritic weathering crusts exposed in Siruka, Choiseul Islands, Solomon Islands, were developed on the expense of serpentinized peridotite underlain by Siruka schists and Voza lavas with a subhorizontal contact. The lateritic profiles consist of three generalized zones: bedrock, saprolitic zone (weathered and decomposed zone) and the limonitic zones. The profiles demonstrate variations in depths and continuity but illustrate mineralogy and geochemical affinity down profile and are analogous to saprolitic nickel laterite deposits. Silica and magnesia in the bed rock and the saprolitic zones have been removed and only the residual elements (iron, chromium, aluminium, manganese, cobalt and nickel) remain in the limonitic zone. These elements are relatively concentrated as a result of the removal of the soluble elements. Nickel is associated with silica and magnesia, as lizardite or mixed gels (garnierite nickel ore) at the weathering fronts. On the other hand, nickel, with generally low concentrations $(<2 \% \mathrm{NiO})$, is also hosted by several secondary mineral phases (goethite and Mn-oxyhydroxides locally) as residuals in the surface limonitic zone. Cobalt, on the other hand, is generally of higher grade (up to $0.9 \% \mathrm{CoO}$ ) and is associated with cryptocrystalline and crystalline manganese-oxyhydroxides. Cobalt and manganese are concentrated in the limonitic part of the profiles ( 3-7m depth) of which are poorly protected against erosion. The behavior of nickel is different from that
\end{abstract}

${ }^{*}$ Corresponding author: C.V. SAGAPOA, Department of Earth Resource Engineering, Faculty of Engineering, Kyushu University, Japan. E-mail: cris-s@mine.kyushuu.ac.jp of cobalt and manganese as its relative mobility is a little higher than them. Nickel is suggested to have been leached out of the limonitic concretions, where it is first concentrated with cobalt and manganese, and migrates to the bottom part of the profiles. Significant supergene nickel enrichment occurring in the saprolitic zone indicated that water had percolated downward to a very low water table at depth during weathering. The structure and mineralogy of the weathering profile is consistent with the alternating wet and dry periods of the studied area.

Keywords: Siruka ultramafic rocks, laterization, Choiseul-Solomon Islands

\section{Introduction}

Nickel laterites are an important resource of nickel and ferronickel and account for approximately $40 \%$ of world annual nickel production (Gleeson et al., 2003). Of the 130 million tonnes (Mt) of nickel in land-based resources containing over $1 \%$ nickel, approximately $60 \%$ is in laterite deposits (USGS Mineral Commodity Summary, 2002). These deposits are produced by the prolonged and deep weathering of ultramafic rocks, such as peridotite, generally in humid tropical to subtropical climates. As a consequence, many recently formed and actively forming deposits are situated in equatorial latitudes, where major producing countries of nickel laterite ores are located (e.g, New Caledonia, Cuba, Philippines, Indonesia, Colombia, and Australia). Studies on nickel deposits coupled with chemical analyses have been widely 
documented (Colin et al., 1990, Golightly , 1981 and Pelletier, 1996). During weathering, some elements become leached (e.g, magnesium, calcium and silicon) and others either are secondarily enriched (e.g, nickel, manganese, cobalt, zinc and yttrium) or residually concentrates (e.g, iron, chromium, aluminum, titanium and zirconium) within laterite profiles (Brand et al., 1998).

Petrography, mineralogy and geochemistry of lateritic weathering crusts developed at the expense of Siruka Peridotites is the focus of attention in this paper. The study considers the chemical behavior of several specific elements (e.g, iron, cobalt, magnesium, chromium, iron, magnesium, aluminium and silicon) and constituent minerals with respect to their depth of occurrence in the weathering profiles, at Siruka, Choiseul, Solomon Islands. Drill hole profile with the ID \#CD0040 was used as a representative profile since it share laterization affinity with the other 14 profiles considered in the study. The annual climatic conditions in the Solomon Islands are tropical and Siruka in Choiseul province is characterized by average precipitation of $3200 \mathrm{~mm} /$ year.

\section{Geology}

The Solomon Islands form an archipelago situated between longitudes $156^{\circ}$ to $170^{\circ} \mathrm{E}$, and latitudes $5^{\circ}$ to $12^{\circ} \mathrm{S}$ (Figure 1). This paper concentrates on the larger islands which form the characteristic NW-SEtrending double chain of islands comprising Choiseul (Figure 2), the New Georgia Group, Santa Isabel, Guadalcanal, Malaita and Makira (or San Cristobal), but with special emphasis on Choiseul. It was conventionally acknowledged that the Solomon block is bounded by two trench systems; the Vitiaz trench to the Northeast and the Britain-San Cristobal trench to the Southwest, later termed as South Solomon Trench System (SSTS) (Petterson et al., 1999). Convergent plate margin tectonics has much control over the structural development of the Choiseul Island which subsequently gives rise to two distinct structural units; (i) the Pre-Miocene igneous and metamorphic basement complex and (ii) the Miocene-Holocene sedimentary and volcanic cover. No radiometric age is yet available for the Choiseul basement sequence but stratigraphic and structural evidence suggest, a probable Cretaceous age (Petterson et al., 1999; Ridgway and Coulson, 1987).

The distribution of rock types in the Choiseul PreMiocene basement is shown on the geological map of southeast Choiseul (Figure 3). The basement includes the Voza Lavas, Choiseul Schists (termed as Siruka Schist locally in here), the Oaka Metamicrogabbro and Siruka Peridotites (Ridgway and Coulson, 1987). This basement sequence of Choiseul is thought to represent an ophiolite complex with mid-ocean ridge basalt (MORB) characteristics, developed close to a subduction zone (Ridgway and Coulson, 1987). The Voza Lavas occur as pillowed, massive and brecciated basalts (Purvis and Kemp, 1975; Ridgway and Coulson, 1987) and can be further divided into two groups; (i) unmetamorphosed and low grade metamorphic rocks and (ii) more highly metamorphosed varieties such as amphibolite facies. The Siruka Schists are considered to be dynamothermally altered Voza Lavas, and are distinct from Voza Lavas in possession of tectonic fabrics. Ridgway and Coulson (1987) suggested that the Siruka Schists were formed by deformation and metamorphism of parts of the original Voza Lava sequence. The Siruka Peridotites are predominantly harzburgites and dunite though lherzolites were also reported by Ridgway and Coulson (1987), and have undergone varying degree of serpentinization. The Siruka Peridotite form a large sheet (Figures 3 and 4) lying on top of Siruka Schists and Voza Lavas with a general subhorizontal contact (Coleman, 1960; Thompson, 1960), hence, are perhaps emplaced as coherent thrust sheet on a subhorizontal plane in Late Miocene to Pleistocene (Thompson, 1960). Field observation showed that the mentioned relationships have been modified by post-emplacement faulting and high angle fault contacts are common. Estimates of the thickness of the emplaced sheet, based on valley bottom to hill crest measurement, show an increasing thickness towards the south (Ridgway and Coulson, 1987). A maximum of $560 \mathrm{~m}$ of 


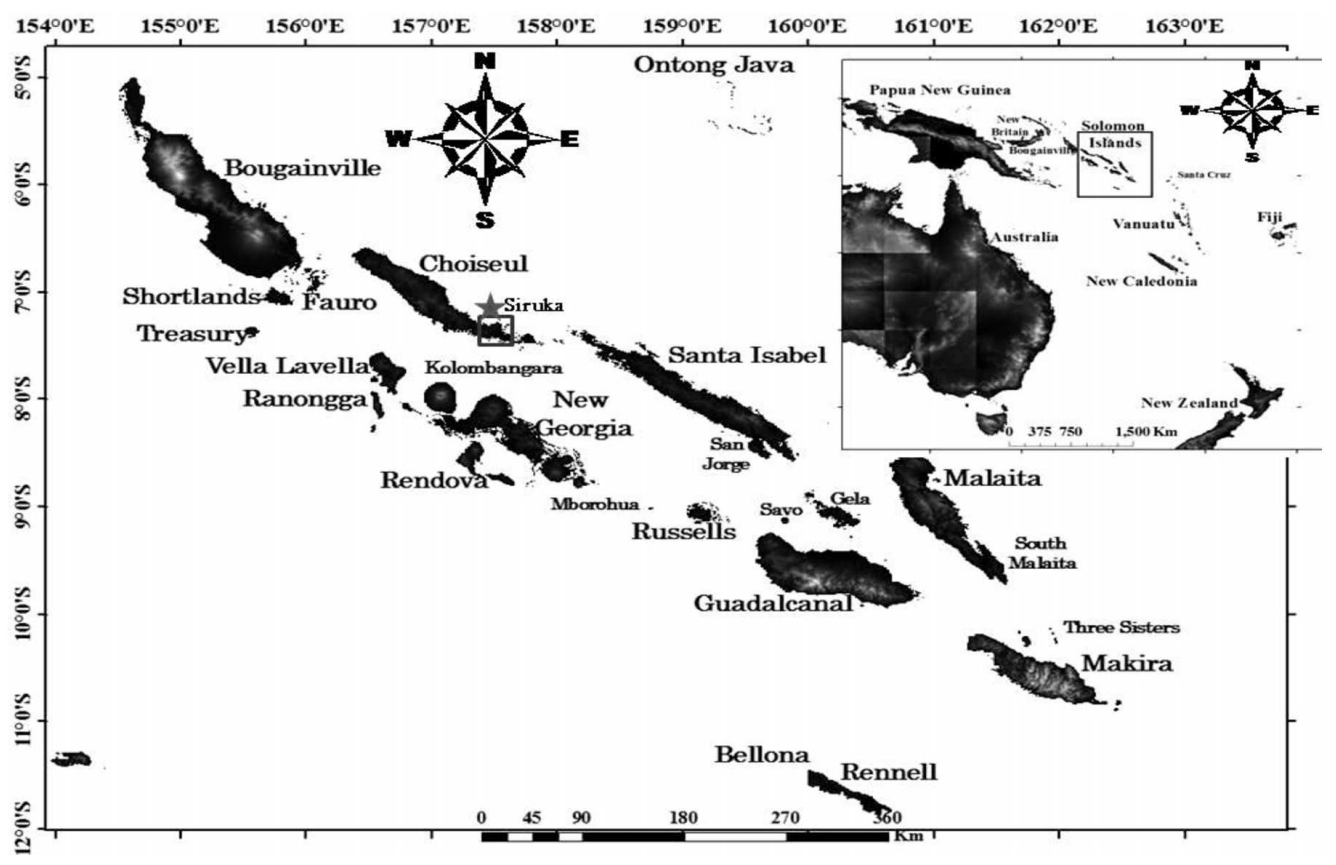

Figure 1: Geographical location of Siruka, Choiseul province, Solomon Islands in the southwest pacific region

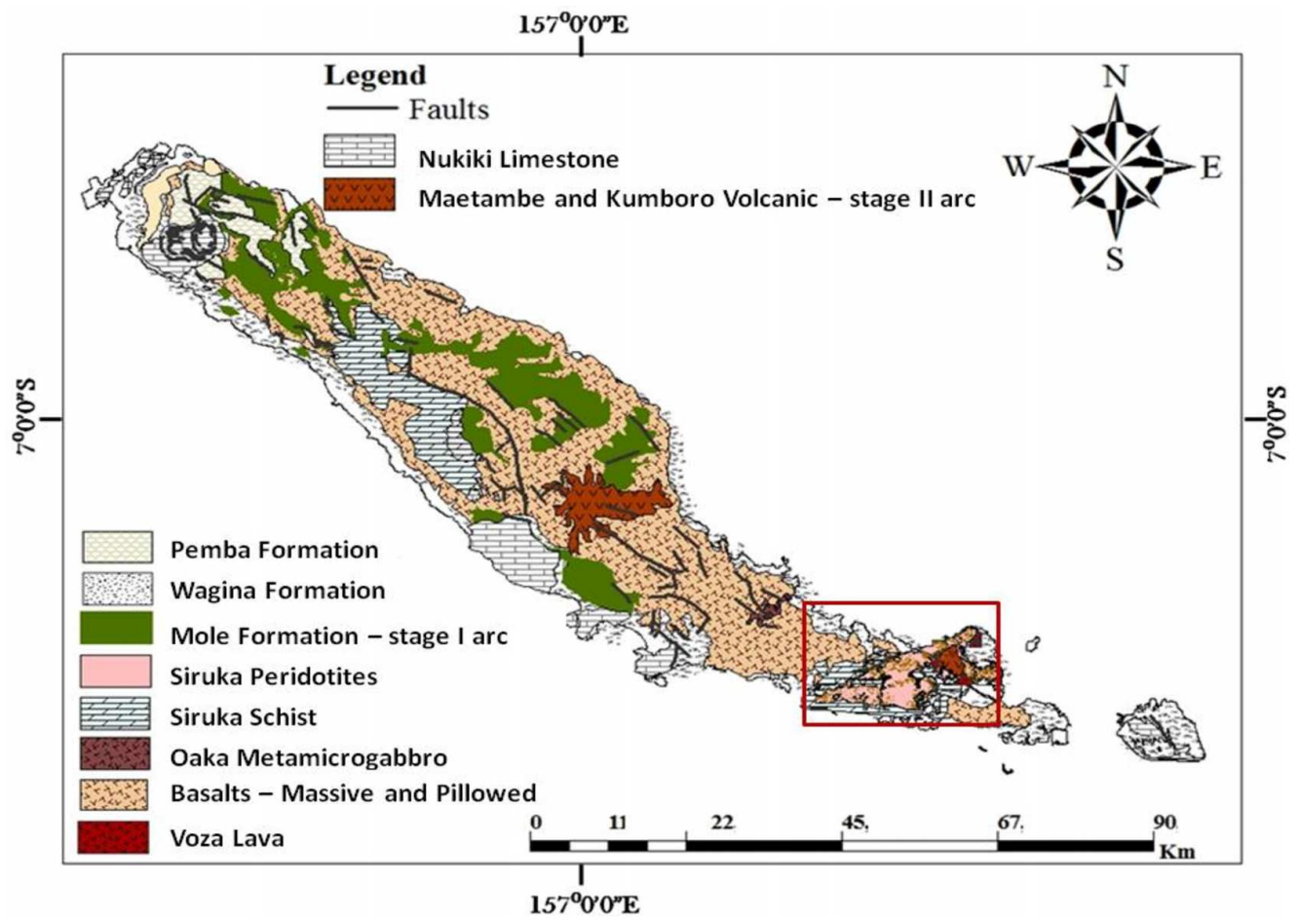

Figure 2: General geology of Choiseul province, Solomon Islands (Modified after Ridgway and Coulson, 1987) 
the emplaced sheet was reported on the south, thinning to $300 \mathrm{~m}$ on the north-west (Ridgway and Coulson, 1987).

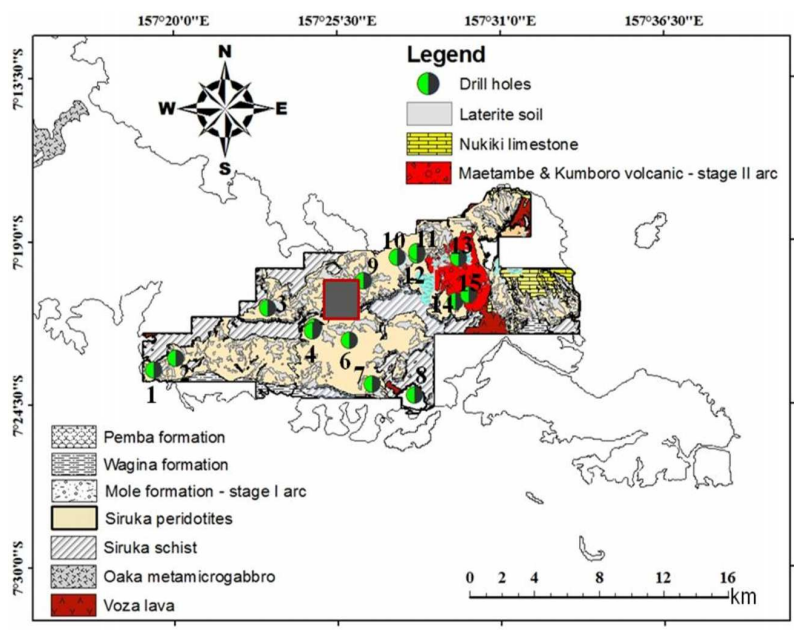

Figure 3: Map illustrating different drill hole localities in this study. Drill hole IDs are represented as 1-15, where $1-$ CD0065; 2 - CD0064; 3 - CD0047; 4-CD0040; 5-CD0041; 6-CH0017; 7 - CC19D001; 8 - CD0053; 9 - CN18D010; $10-$ CN02D004; 11 - CD0001; 12 - CN01D006; 13 CH004; $14-$ CD0066 and 15 - CE15D001. (Modified after SMM Solomon Ltd)

The sedimentary and volcanic cover ranges in age from Miocene to Recent and are arranged in order of decreasing age (Ridgway and Coulson, 1987) which includes Mole Formation Kumboro and Maetambe Volcanics (Early Middle Miocene); Wagina Formation (Early Pliocene); Pemba Formation (Early to Late Pliocene); Nukiki Limestone Formation backreef and lagoonal deposits (Pliocene); Holocene Deposits including alluvium, mangrove and freshwater swamp; backreef and lagoonal facies sediments and coralline reef limestones (Holocene). However, recent work by Petterson et al. (1997) suggested that stage 1 arc development is represented by crystal and lithic-rich turbidites from the Mole Formation whereas the Kumboro and Maetambe Volcanics constitute the stage 2 arc sequence of the Solomon Islands tectonism.

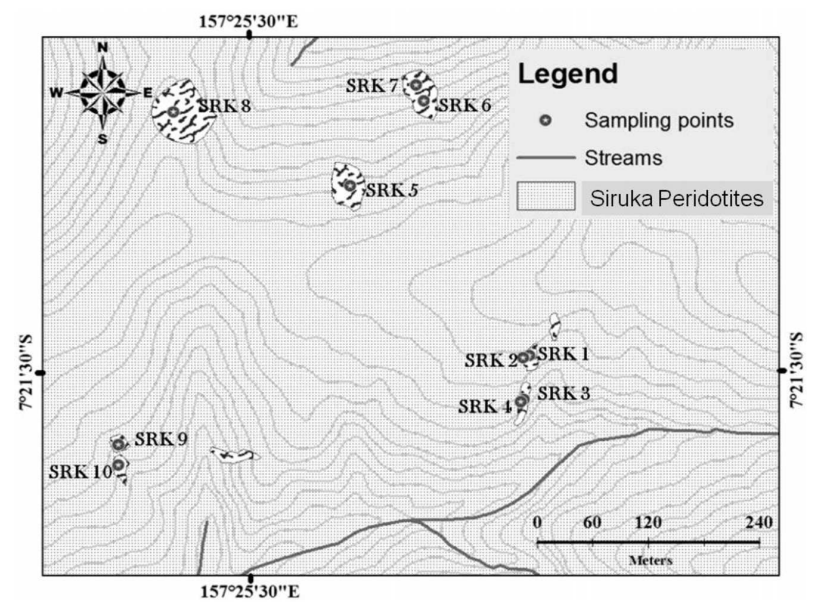

Figure 4: Expanded illustration of hand sampling sites denoted by 'dark grey' square (see Fig 3) on the geological map (modified after SMM Solomon Ltd)

\section{Analytical methods}

Sampling of lateritic profiles was carried out on cores drilled by SMM Solomon Ltd, Solomon Islands, in the Siruka ultramafic rocks. Bulk chemical compositions of samples were determined by combined X-ray fluorescence (XRF) technique. Major and trace elements were determined using X-ray fluorescence (RigakuRIX 3100) at the Department of Earth Resource Engineering, Kyushu University, Japan. Xray diffraction (XRD) analyses of clay minerals were done on oriented mounds, using an X-ray diffractometer (Rigaku RINT 2100) at room temperature, using $\mathrm{Cu} \mathrm{K} \alpha$ target with a voltage of $40 \mathrm{kV}$ and a current of $20 \mathrm{~mA}$ at the Department of Earth Resource Engineering, Kyushu University. Electromicroprobe analyzer (EPMA) was used for mineral chemistry analysis. Chemical composition of the rock forming minerals in the studied serpentinites were acquired using JXA-8800R under operating condition of $15 \mathrm{kV}$ and $20 \mathrm{nA}$, with suitable synthetic and natural mineral (silicates) standards for calibration purposes at the International Centre for Research and Education on Mineral and Energy Resources, Akita University, Japan. 


\section{Petrography of Siruka peridotites}

From hand specimen, the Siruka Peridotites appear to be mostly grayish to dark greenish in color with interlocking textures. The studied peridotites include massive and sheared varieties. Those exposed on the surface appear greenish to dark colored. The green color of the exposed peridotites were presumably due to their olivine content and their darker features are attributed to increasing abundance of serpentine and iron oxide mineral content within the samples.

Petrographically, the primary constituent minerals of the Siruka ultramafic rocks are olivine, pyroxene and spinel. Mineral assemblages and abundances of ultramafic rocks from Siruka were estimated from observation on thin-sections (Table 1). Obvious uneven composition of orthopyroxene is attributed to varying degree of serpentinisation and the abundance of orthopyroxene over clinopyroxene is probably attributed to the degree of melting. The peridotites are typically cross-cut by vein (Figure 5A), recording a complex history of fracturing and fluid circulation. The abundance and orientation of veins is variable however, observed parallel veins is apparent (Figure 5B). In serpentinite schist (e.g, SRK8), the original texture has been completely modified presumably by deformation and recrystallization as illustrated by talc, which occurred in very fine grain ground mass as flakes (Figure 5C). Texturally, the peridotite drilled cores are characterized by prevalence of mesh and bastite textures (Figure 5D).

Peridotites associated with laterization in Siruka partially preserve geometric configurations of the original primary minerals, where serpentine developed as an alteration after olivine has a mesh texture while that formed after alteration orthopyroxene has a bastite texture. Chrysotile occurs as veinlets traversing matrixes and lizardite occur as minor grains replacing olivine (Figure 5E). Within the mesh textures, broken olivine fragments were replaced by concentric layers of serpentine aggregates commonly associated with magnetite grains (Figure 5 F). The opaque minerals in the studied peridotites are represented predominantly by $\mathrm{Mg}$-Al-chromite and magnetite. Amphibole is identified as tremolite and magnesiohornblende. Spinel is commonly dark and opaque; only the euhedral shaped and fine grained spinels host magnetite in Siruka. Talc and amphibole are commonly associated with altered orthopyroxene and serpentine (Figure 5G). In general, the sampled Siruka Peridotites are characterized essentially of amphibole, chrysotile and lizardite, with subordinate amounts of magnetite, talc, magnesite, brucite (Figure 5 $\mathrm{H}$ ), and chlorite. Magnesite is associated with opaques (spinel) as well as chlorite veins.

\section{Field observation and mineralogy}

Lateritic profiles in Siruka, following observation of fifteen drill holes, show variations in thickness and continuity for individual layers in the profiles. Differences are also observed in the mineralogy and chemistry of the zones over short distances. Intense post-erosion processes are unlikely after laterization in Siruka, however, possibilities of erosion cannot be absolutely ruled off considering the incline geomorphology of the study area. Due to lack of intense erosion, ferruginous zones are well developed, referred to limonite 1 (L1), limonite 2 (L2) and limonite 3 (L3), is possible. L3 is a brown homogeneous argillic soil horizon, L2 is banded yellowish orange argillic horizon and L1 is goethite and hematite enriched brown homogeneous silty soil horizon. Though varied in depths, mineralogy for most other drilled hole cores considered were analogous to that of our representative drilled hole (CD0040). CD0040 is used as the representative drill hole for discussion in this paper and is characterized as; (a) bedrock (protolith), (b) saprolitic zone (weathering and decomposed zone and (c) limonitic zone (Figure 6).

The bedrock is mostly serpentinized harzburgite and grades into the saprolitic zone. Hard and relatively substantial fragmented rock boulders or pebbles were observed at the lower saprolite zone (referred to as weathering front) which gradually grades upward into soft and 

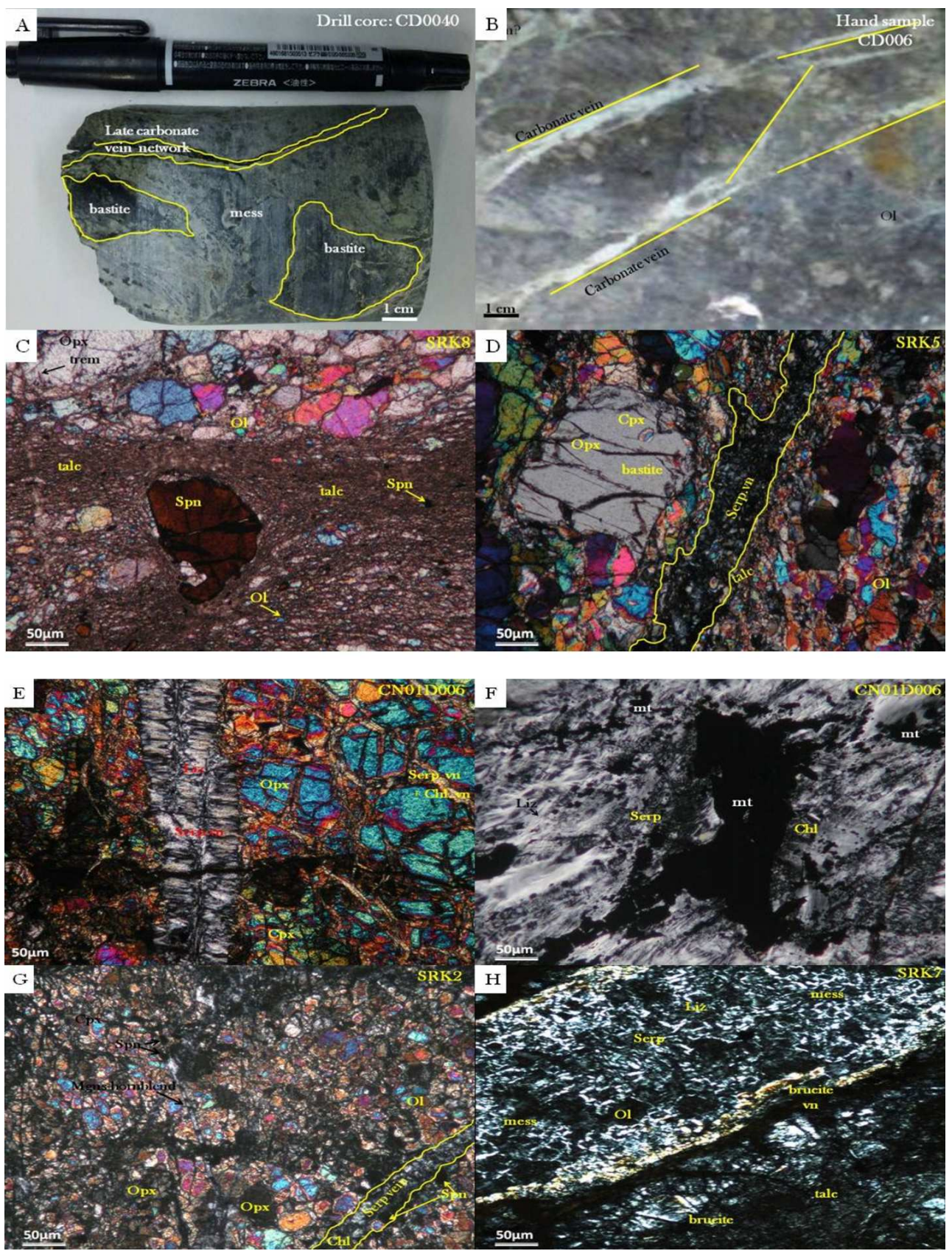

Figure 5: Photomicrograph showing the main textures and minerals associated with the serpentinized Siruka peridotite. (A) Sample ID: CD0040, locality: 324695(E), 9185608(N) and (B) Sample ID: CD0066; locality: 331098(E), 9190103(N); hand samples illustrate carbonate network veining. (C) Sample ID: SRK8, locality: 326074(E), 9186622(N); altered olivine (Ol) grain with patches of dark spinel (Spn) grains in association with orthopyroxene (Opx), tremolite (trem) and talc [XPL]. (D) Sample ID: SRK5, locality: 326625(E), 9186540(N); orthopyroxene (Opx) with associated exsolved clinopyroxene (Exslv.Cpx) on grain boundaries coupled with talc matrix [XPL]. (E) Sample ID: CN01D006, locality: 331098(E), 9190103(N); chrysotile (Ctl) and chlorite (Chl) veins with grains of lizardite (liz) [XPL]. (F) Sample ID: CN01D006; magnetite (mt) grain, chlorite (Chl) grain plus serpentine on the spinel grain boundary [PPL]. (G) Sample ID: SRK2, locality: 326452(E), 9186349(N); magnesio-hornblende with disseminated Opx grains [XPL]. (H) Sample ID: SRK7, locality: 326336(E), 9186652(N); typical serpentine lizardite vein bounded by reddish orange brucite veins [XPL]. Localities are expressed in UTM coordinates (WGS 84) 
Table 1: Petrological and mineralogical characteristics of Siruka Peridotites, Choiseul, Solomon Islands

\begin{tabular}{|c|c|c|c|c|c|c|c|c|c|c|}
\hline \multicolumn{3}{|c|}{ Description } & \multicolumn{4}{|c|}{ Primary Assemblage } & \multicolumn{4}{|c|}{ Secondary assemblage } \\
\hline & & & & & & & & & & Others \\
\hline Sample & Rock type & Texture & OI & Opx & Cpx & Spn & Serp & Amp & Chl & (e.g. talc and \\
\hline No. & (Peridotite) & & $(\%)$ & $(\%)$ & $(\%)$ & $(\%)$ & & $(\%)$ & $(\%)$ & brucite etc) \\
\hline SRK1 & Dunite & Sheared & 90 & 8 & 1 & 0.2 & Yes & - & - & \\
\hline SRK2 & Dunite & Protogranulitic & 92 & 6 & 1 & 0.4 & Yes & Yes & - & \\
\hline SRK3 & Dunite & Sheared & 93 & 7 & 2 & 0.3 & Yes & Yes & Yes & \\
\hline SRK4 & Dunte & Sheared & 95 & 8 & 2 & 0.1 & Yes & - & - & \\
\hline SRK5 & Dunite & Sheared & 97 & 5 & 1 & - & Yes & Yes & - & \\
\hline SRK6 & Hurzburgite & Strongly Sheared & 74 & 21 & 4 & 0.8 & Yes & - & - & \\
\hline SRK7 & Hurzburgite & Sheared & 67 & 24 & 5 & 1.1 & Yes & Yes & & \\
\hline SRKB & Hurzburgite & Porphyroclastic & 74 & 21 & 3 & 0.5 & Yes & - & Yes & \\
\hline SRK9 & Hurzburgite & Protogranular & 69 & 22 & 5 & 1.5 & Yes & Yes & - & \\
\hline SRK10 & Hurzburgite & Strongly Sheared & 72 & 22 & 3 & 0.6 & Yes & Yes & - & \\
\hline CD0040 & Hurzburgite & Sheared/mesh & 73 & 18 & 4 & 0.5 & Yes & - & Yes & \\
\hline CD0041 & Hurzburgite & Mesh textured & 75 & 20 & 1 & 0.8 & Yes & Yes & Yes & \\
\hline CN01D006 & Hurzburgite & Sheared/mesh & 73 & 22 & 4 & 0.7 & Yes & Yes & Yes & \\
\hline
\end{tabular}

*Abbreviations: Olivine, Ol; Orthopyroxene, Opx; Clnopyroxene, Cpx; Spinel, Spn; Seperntine, serp; Amphibole, Amp; and Chlorite, Chl. Modal composition estimate is after point counting. ${ }^{*}$ 'Yes' indicates presence of the listed minerals

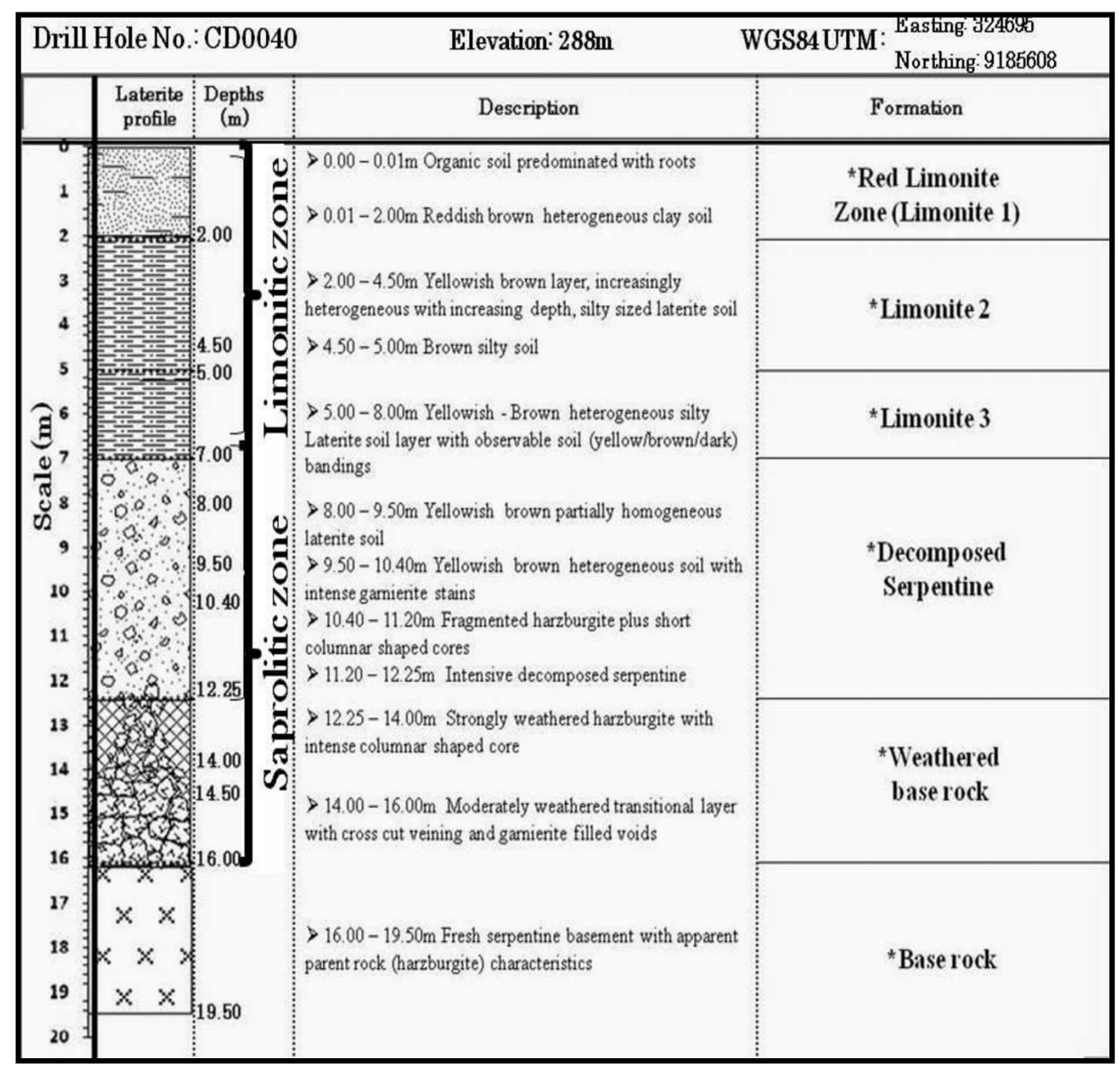

Figure 6: Schematic laterite profile in the Siruka nickel laterite deposit, Choiseul, Solomon Islands. Note both the weathering zone and the decomposed zone are grouped as 'saprolitic zone' 
argillized decomposed zone. The lower saprolitic zone is occasionally transected by loose talc, garnierite and carbonate veins. The fragmented boulders in the lower yellowish green to brown saprolitic zone still retain the mineral textures of the original rock. Filling of voids and cracks by garnierite is commonly observed in this horizon yielding higher nickel concentration ( avg. 1.5\%).

Locally, within the saprolite zone, areas of intense secondary veining and boxworks are commonly observed. These can naturally go after relic structures, fractures, and grain boundaries and can contain neo-formed quartz and Ni-rich minerals such as the distinguishing green mineral garnierite (Gleeson et al., 2003). The transition to the limonitic zone is marked by gradual disappearance of yellowish darkgreen serpentine into smectite unit (observable at $\sim 8 \mathrm{~m}$ depth for CD0040). Dark manganese oxide blebs or nodules are commonly observed in L1 zone within the oxide matrix associated with the surface organic zone which randomly host visible iron crusts.

Compared to the basement rock mineralogy, the primary mineralogy and texture of the host rock are totally destroyed in the encrusted limonite zone. XRD results of bulk serpentinite reveal distinct peaks for the serpentine polymorphs, chrysotile and lizardite, trevorite, magnesite and amphibole and talc (Figure 7). Nevertheless, between $\sim 10-12$ m depths, relicts of serpentine and talc were still detected by XRD (Figures $8 \mathrm{~A}$ and $8 \mathrm{~B}$ ). The limonitic zone is soft and friable consisting goethite, gibbsite, hematite, and traces of magnetite-maghemite (Figures $8 \mathrm{C}$ and $8 \mathrm{D}$ ). Geochemical analysis of the various drilled hole profiles at Siruka also shows geochemical affinities to that of CD0040 (Table 2). The regolith thicknesses of each drill holes still differ regardless of whether the profile is on the same parent rock. Basaltic rocks collected from drilled holes (CD0064, CD0065 and CE15D001) indicated no nickel enrichment.

Mineralogy evaluation on the representative profile (CD0040) show inconsistent mode of occurrence with respect to the parent rocks in Siruka. Specific individual minerals show varying modal occurrence up the weathering pro- files. Table 3 shows enriched olivine content on the basement which is anticipated for harzburgites however is gradually depleting as you move up the profile. The occurrence of spinel minerals (chromite and magnetite) in the parent rock and their quick termination indicates well on their instability nature in highly oxidized settings. Goethite, hematite and kaolinite are predominant minerals alternating the primary minerals. Gibbsite on the other hand is highly enriched on the most surface samples coherent to enriching behaviour of $\mathrm{Al}_{2} \mathrm{O}_{3}$.

\section{Mass balance calculations}

Mass balance evaluation was carried out to evaluate element distribution during supergene weathering processes in Siruka. In very intense weathering conditions, the mobility of refractory elements such as $\mathrm{Al}, \mathrm{Zr}, \mathrm{Ti}$ and $\mathrm{Th}$ was demonstrated (Mungall and Martin, 1994; Nahon and Merino, 1997; Kurtz et al., 2000), thus they are unreliable to use as immobile element. According to Braun et al. (2005), the mobility of refractory elements can also depend on the presence of organic ligands in soil solution.

In the process of evaluating gains and losses during supergene weathering at Siruka, we did not try to estimate volume changes due to the vast limonite thickness. We choose assumed immobile element approach which was employed successfully by previous authors on weathered rocks (e.g. Moroni et al., 2001). The percentage gain or loss in the concentration of each element in weathered samples was compared with that of the parent rock according to equation.

$$
\% \text { change }=\left[\frac{X_{a} / I_{a}}{X_{u} / I_{u}}-1\right] \times 100
$$

Where $X_{a}$ and $X_{u}$ are the element concentration in the weathered sample and the parent rock respectively. On the other hand, $I_{a}$ and $I_{u}$ are the concentration of immobile element in the weathered sample and the parent rock, respectively.

It is quite complicated to try and identify any best suitable element that is truly immobile in the laterites from Siruka since all components 


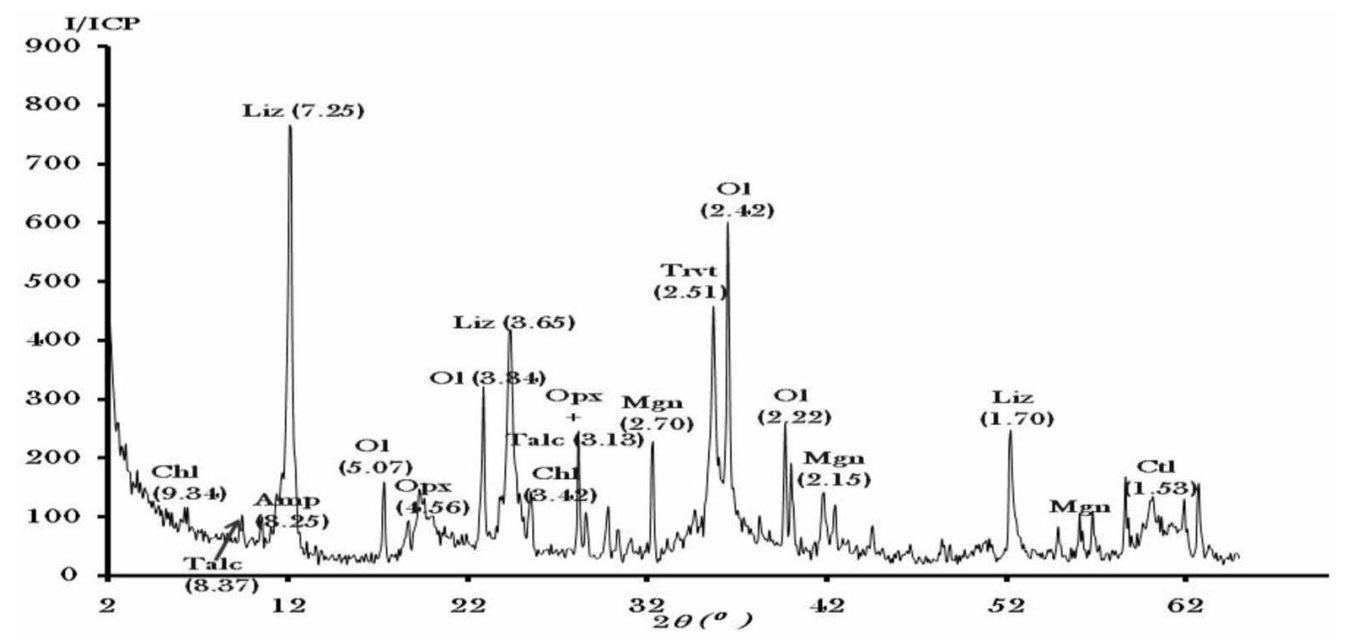

Figure 7: XRD patterns of serpentinized peridotite (specifically CD0040 protolith unit - at 19.50m depth) from Siruka. The spectrum was obtained using an X-ray diffractometer 'Rigaku' at room

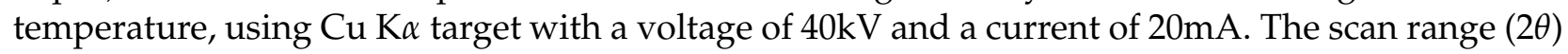
was 2-65 ${ }^{\circ}$ with a step size of $0.02^{\circ}$. Olivine $=\mathrm{Ol}$, Chlorite $=\mathrm{Chl}$; Amphibole $=$ Amp, Chrysotile $=$ $\mathrm{Ctl}$, Lizardite $=\mathrm{Liz}$, Orthopyroxene $=$ Opx, Magnesite $=$ Mgn, Trevorite $=$ Trvt and talc

Table 2: Geochemical composition variation occur with depth, CD0040 drill hole ( ${ }^{*}$ representative profile in Siruka)

\begin{tabular}{|c|c|c|c|c|c|c|c|c|c|c|}
\hline & \multirow{4}{*}{$\begin{array}{l}\text { Parent rock: } \\
\begin{array}{l}\text { Drill Hole } \\
{ }^{*} \text { CDO040 }\end{array}\end{array}$} & \multicolumn{9}{|c|}{ Siruka weathering material } \\
\hline & & \multicolumn{4}{|c|}{ Saprolitic zone } & \multicolumn{5}{|c|}{ Limonite zone } \\
\hline & & \multicolumn{2}{|c|}{ Weathering front } & \multicolumn{2}{|c|}{ Decomposed zone } & \multicolumn{2}{|c|}{ Limonite 3} & \multicolumn{2}{|c|}{ Limonite 2} & \multirow[t]{2}{*}{ Limonite 1} \\
\hline & & base & top & base & top & base & top & base & top & \\
\hline Depths (m) & 19.50 & 19.00 & 17.50 & 15.50 & 12.50 & 9.50 & 7.50 & 5.00 & 2.50 & 0.50 \\
\hline SiO2 (Wt \%) & 39.68 & 36.86 & 35.16 & 33.63 & 26.09 & 12.67 & 9.54 & 3.84 & 2.3 & 2.07 \\
\hline TiO2 & 0.01 & 0.01 & 0.01 & 0.01 & 0.01 & 0.01 & 0.01 & 0.01 & 0.01 & 0.01 \\
\hline $\mathrm{A} 12 \mathrm{O} 3$ & 1.06 & 1.04 & 1.03 & 2.53 & 9.69 & 16.2 & 15.2 & 11.5 & 11.3 & 12.3 \\
\hline $\mathrm{FeO}^{*}$ & 6.37 & 7.07 & 8.60 & 10.6 & 10.9 & 39.1 & 50.6 & 51.9 & 51.4 & 52.5 \\
\hline Mno & 0.11 & 0.1 & 0.12 & 0.13 & 0.15 & 0.17 & 0.14 & 0.16 & 0.07 & 0.05 \\
\hline MgO & 39.7 & 37.8 & 35.9 & 24.3 & 24.8 & 0.43 & 0.45 & 2.75 & 1.18 & 0.47 \\
\hline $\mathrm{CaO}$ & 0.02 & 0.02 & 0.01 & 0.03 & 0.07 & bdl & bdl & bdl & bdl & bdi \\
\hline $\mathrm{Na} 2 \mathrm{O}$ & 0.02 & bdl & bdl & bdl & bdl & bdl & bdl & bdl & bdI & bdl \\
\hline $\mathrm{K} 2 \mathrm{O}$ & 0.03 & bdl & bdl & bdl & bdl & bdl & bdl & bdl & bdl & 0.01 \\
\hline P2O5 & 0.02 & 0.01 & 0.01 & 0.01 & 0.01 & 0.01 & 0.01 & 0.01 & 0.01 & 0.01 \\
\hline LOI & 11.9 & 13.9 & 16.7 & 14.5 & 15.5 & 16.2 & 12.4 & 15.4 & 15.2 & 19.3 \\
\hline Total & 98.8 & 96.8 & 97.6 & 85.7 & 87.2 & 84.8 & 88.3 & 85.5 & 81.4 & 86.7 \\
\hline Cr (ppm) & 2317 & 2464 & 2410 & 2380 & 2426 & 2310 & 2379 & 2445 & 2227 & 2242 \\
\hline
\end{tabular}



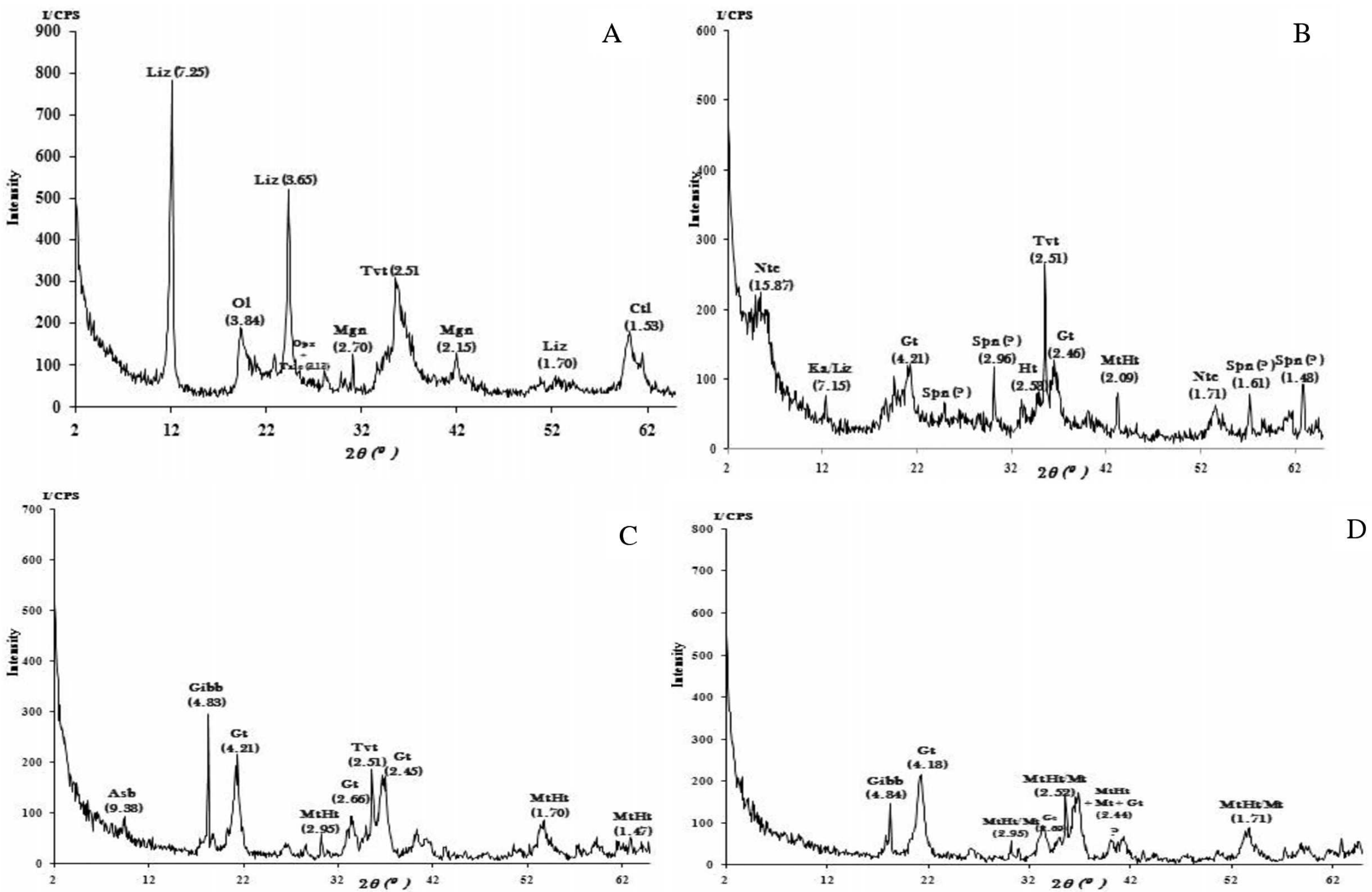

Figure 8: XRD patterns of CD0040 protolith unit from Siruka. $A=12 \mathrm{~m}, \mathrm{~B}=8 \mathrm{~m}, \mathrm{C}=5 \mathrm{~m}$ and $\mathrm{D}=3 \mathrm{~m}$ depth samples respectively. Olivine $=$ Ol, Chlorite $=$ Chl; Amphibole $=$ Amp, Chrysotile $=$ Ctl, Lizardite $=$ Liz, Orthopyroxene $=$ Opx, Magnesite $=$ Mgn, Trevorite $=$ Trvt, Maghemite 


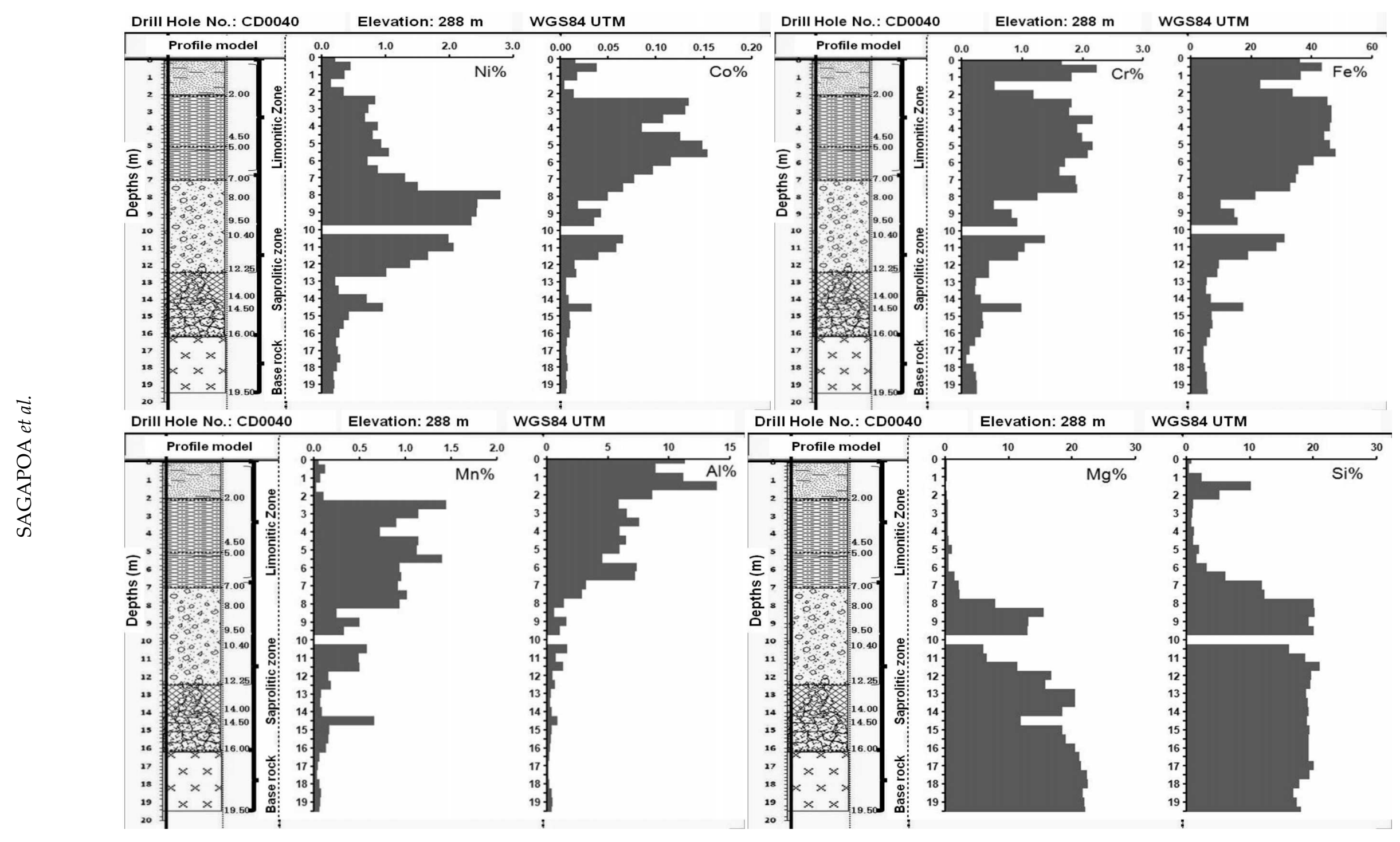

Figure 9: Model graphical representation of elemental distribution in Siruka weathering profiles. Here Ni, Co, Cr and Fe are consistent with calculated correlation factors on each zone in the profile 
Table 3: Mineralogical composition of the parent Siruka Peridotite and its weathered products in the representative profile (CD0040)

\begin{tabular}{|c|c|c|c|c|c|c|c|c|c|c|}
\hline & \multirow{4}{*}{$\begin{array}{l}\text { Parent rock: } \\
\text { Dril Hole ID } \\
{ }^{ \pm} \text {CD0040 }\end{array}$} & \multicolumn{9}{|c|}{ Siruka weathering material } \\
\hline & & \multicolumn{4}{|c|}{ Saprolitic zone } & \multicolumn{5}{|c|}{ Limonite zone } \\
\hline & & \multicolumn{2}{|c|}{ Weathering front } & \multicolumn{2}{|c|}{ Decomposed zone } & \multicolumn{2}{|c|}{ Limonite 3} & \multicolumn{2}{|c|}{ Limonite 2} & \multirow[t]{2}{*}{ Limonite 1} \\
\hline & & base & top & base & top & base & top & base & top & \\
\hline Depths (m) & 19.5 & 19.0 & 17.5 & 15.5 & 12.5 & 9.5 & 7.5 & 5.0 & 2.5 & 0.5 \\
\hline Olivine & +++ & ++ & ++ & + & - & - & - & - & - & - \\
\hline Orthopyroxene & +++ & ++ & ++ & + & - & - & - & - & - & - \\
\hline Clinopyroxene & + & + & + & - & - & - & - & - & - & - \\
\hline Chromite & + & + & - & - & - & - & - & - & - & - \\
\hline Magnetite & + & + & - & - & - & - & - & - & - & - \\
\hline Goethite & - & - & - & - & + & + & ++ & +++ & +++ & ++ \\
\hline Hematite & - & - & - & - & - & + & +t & ++ & + & + \\
\hline Kaolinite & - & - & - & - & + & + & ++ & +++ & + & + \\
\hline Lizardite & + & + & + & + & + & - & - & - & - & - \\
\hline Chrysotile & + & + & + & - & - & - & - & - & - & - \\
\hline Gibbsite & - & - & - & + & + & ++ & ++ & ++ & ++ & +++ \\
\hline
\end{tabular}

*Mode of occurrence abbreviations: ++++ , very abundant; +++ , abundant; ++ , represented; + , poorly represented; +, traces; -, not identified

of the parent rock have been removed to varying degrees. Moreover, most of the trace element results recovered in this work present a concentration very near to their detection limit, therefore complicate choices for any best fit elements. According to Ndjigue et al. (2008) if an element present at its detection limit in the parent material is used in equation above (Equation 1), a difference in its concentration in the last decimal place can lead to wide change in the calculated \% change. Because of this phenomenon, a reflective element with relatively higher concentration in the parent rock is chosen. From which we calculate \% changes for most other elements, assuming that the element chosen is the least mobile than the others. Applying this decisive factor and according to Nesbitt and Wilson (1992), chromium is the opted immobile element for Siruka samples compared to $\mathrm{TiO}_{2}$ or $\mathrm{Zr}$. The parent peridotites at Siruka are used for the mass balance calculation. Relative to chromium, practical application of Equation 1 illustrate apparent removal of most major and trace element in amounts exceeding $\sim 80 \%$ of the original concentration in the parent body prior to weathering (Table 4). Enrichment and distribution of minor and trace elements in the laterites are often controlled by weathering processes and morphology of the peridotite massifs (Marker et al., 1991).

Mass balance evaluation tabulated in Table 4 clearly singled out $\mathrm{SiO}_{2}$ and $\mathrm{MgO}$ to be the most leached major elements out of all the other in the profile though $\mathrm{MgO}$ is more depleted as weathering intensifies towards the surface of the profiles. $\mathrm{SiO}_{2}$ is very unstable in surface environment and on top of that its depleting behavior is attributed to heavy leaching during dissolution and laterization process. The depleted behavior of $\mathrm{MgO}$ is attributed to its almost complete ionic exchange reaction with $\mathrm{Ni}$ during dissolution and obliteration of the silicates. On the other hand, $\mathrm{MnO}$ illustrate variable behavior however, prominent enrichment in the decomposed and Limonite transition zone is consistent with the presence of asbolane minerals in these zones. $\mathrm{Na}_{2} \mathrm{O}$ and $\mathrm{K}_{2} \mathrm{O}$ are very low in Siruka thus are recorded to be below detection limit in the weathering horizons. Similar to $\mathrm{Na}_{2} \mathrm{O}$ and $\mathrm{K}_{2} \mathrm{O}, \mathrm{TiO}_{2}$ also illus- 
Table 4: Mass balance evaluation (in \%) for CD0040 profile, Siruka, Solomon Islands

\begin{tabular}{|c|c|c|c|c|c|c|c|c|c|}
\hline \multirow{4}{*}{$\begin{array}{l}\text { Parent rock: } \\
\text { Sample dril Hole } \\
{ }^{*} \text { CD0040 }\end{array}$} & \multicolumn{9}{|c|}{ Weathering material at Siruka } \\
\hline & \multicolumn{4}{|c|}{ Saprolitic zone } & \multicolumn{5}{|c|}{ Limonite zone } \\
\hline & \multicolumn{4}{|c|}{ Weathering front Decomposed zone } & \multicolumn{2}{|c|}{ Limonite 3} & \multicolumn{2}{|c|}{ Limonite 2} & \multirow[t]{2}{*}{ Limonite 1} \\
\hline & base & top & base & top & base & top & base & top & \\
\hline Depths (m) & 19.00 & 17.50 & 15.50 & 12.50 & 9.50 & 7.50 & 5.00 & 2.50 & 0.50 \\
\hline $\mathrm{SiO} 2(\mathrm{Wt} \%)$ & -12.7 & -14.8 & -17.5 & -37.2 & -68.0 & -76.6 & -90.8 & -94.0 & -94.6 \\
\hline TiO2 & -5.97 & -3.86 & -2.65 & -4.49 & 0.30 & -2.61 & -5.24 & 4.04 & 3.35 \\
\hline $\mathrm{Al} 2 \mathrm{O} 3$ & -7.50 & -6.33 & 133 & 775 & 1436 & 1296 & 926 & 1010 & 1101 \\
\hline $\mathrm{FeO}^{*}$ & 4.32 & 29.7 & 62.1 & 63.5 & 516 & 673 & 671 & 739 & 751 \\
\hline MnO & -14.5 & 4.88 & 15.1 & 30.2 & 55.0 & 24.0 & 37.8 & -33.8 & -53.0 \\
\hline $\mathrm{MgO}$ & -10.4 & -13.0 & -40.4 & -40.4 & -98.9 & -98.9 & -93.4 & -96.9 & -98.8 \\
\hline $\mathrm{CaO}$ & 13.0 & -45.0 & 67.1 & 282.4 & bdl & bdl & bdl & bdl & bdl \\
\hline $\mathrm{Na} 2 \mathrm{O}$ & bdl & bdl & bdl & bdl & bdl & bdl & bdl & bdl & bdl \\
\hline $\mathrm{K} 2 \mathrm{O}$ & bdl & bdl & bdl & bdl & bdl & bdl & bdl & bdl & bdl \\
\hline P2O5 & -48.8 & -47.7 & -47.0 & -48.0 & -45.4 & -47.0 & -48.4 & -43.4 & -43.7 \\
\hline $\mathrm{Cr}(\mathrm{ppm})$ & 2464 & 2410 & 2380 & 2426 & 2310 & 2379 & 2445 & 2227 & 2242 \\
\hline
\end{tabular}

${ }^{*}$ Chromium $(\mathrm{Cr})$ is the assumed immobile element therefore used as the normalizing element

trate low values and its variable behavior in the surface horizons is attributable to the elevated oxidation interaction in the oxidized region.

Table 4 shows apparent enrichment of $\mathrm{FeO}^{*}$ and $\mathrm{Al}_{2} \mathrm{O}_{3}$ as weathering increases in the profiles at Siruka and this behavior is consistent with the increased proportion of goethite and gibbsite observed in the surface horizons of the studied profiles. Chemical analyses and massbalance calculations suggest that progressive weathering of the parent rock is characterized by an enrichment of iron, cobalt, chromium, aluminium and manganese on the limonite zone, an incorporation of nickel at the boundary between the bedrock and the saprolite and in the lower part of the limonite, and a depletion of magnesium and silicon.

\section{Discussion}

Chemical analyses were performed on the samples taken for each half a meter $(0.5 \mathrm{~m})$ thickness from fifteen (15) drill holes at Siruka for this study, three of which share basaltic basement. Distribution model of elements on the diagnosed weathering profiles (Figure 9) share similar patterns of nickel distribution as sapro- litic laterites elsewhere in the world (e.g, New Caledonia and Cuba, Gleeson et al., 2003).

Based on petrography, mineralogy and geochemistry of the parent samples studied, schematic process affecting the peridotites which subsequently gave rise to the development of the weathering crust in Siruka is characterized by, (i) obliteration of bed rock which resulted in dissolution and (ii) subsequent limonitization. During obliteration and dissolution stage, smectites form and incorporated with the chromium presumably released during primary minerals alteration. But, as the weathering proceeds mobile elements like magnesium and silicon are preferentially leached (Bonifacio et al., 1997), leaving less mobile elements, like iron, chromium and aluminium in the profiles and form substituted oxides. Coherently, we suggested that the leaching process of magnesium is attributed to the formation of nontronite depicted by XRD on the profiles (see Figure 8). Presence of nontronite is in agreement with the results presented by Bosio et al. (1975) and Decarreau et al. (1987), who found nontronite in the Jacuba garnierite.

This post-serpentinization process results in replacement of magnesium by nickel. The magnesium replacement process could be attributed 
to an ionic exchange reaction such as: $\mathrm{Mg}$ serpentine $+\mathrm{Ni}^{2+}=\mathrm{Ni}$-rich serpentine $+\mathrm{Mg}^{2+}$. Subsequent to the dissolution process is the limonitization, which involve crystallization of Fe oxyhydroxides (e.g, goethite and hematite) dominant in the overlying limonite horizon at Siruka. According to Becquer et al. (2006) and Garrnier et al. (2006), aluminium, chromium and nickel released during the weathering of primary minerals can be incorporated into iron oxides. This oxide rich portion of the profile is referred to informally as limonite and the volume of the upper collapsed portion may be as little as $\sim 15 \%$ of the original rock (Golightly, 1981).

Siruka profiles illustrate manganese oxides to be mainly concentrated at interface between the limonite zone and the saprolitic zone. According to Butt and Sheppy (1975), high Eh and low $\mathrm{pH}$ conditions often prevail at interfaces between the most surface limonite zone and the saprolite, a region where manganese oxides can coprecipitate with nickel, cobalt and other elements. This could explain the coexistence of manganese and cobalt in the profiles at Siruka. According to Llorca (1993) manganese is leached from olivine, pyroxene, coupled with their metamorphic products, and precipitated as manganese oxides however, were limited to certain horizons and depths. Manganese oxide in Siruka was suggested to have precipitated and form significant manganesecobalt-nickel enrichment, coherent to those in Ora Banda-Siberia area of Western Australia (e.g, Elias et al., 1981) and equivalently alluded to by Kuck (1992) in New Caledonia. Considering the significant correlation between manganese oxide and cobalt oxides, Roorda and Queneau (1973) suggested that manganese oxyhydroxides would be the main carriers of cobalt and in some cases nickel. In silicate laterites in New Caledonia (Llorca and Monchoux, 1991) and even in clayey laterites in Western Australia (Wells, 2003), cobalt mineralization is principally associated with manganeseoxyhydroxides (asbolane-lithophorite group). Manganese enrichment in Siruka is attributed to occurrence of asbolane group manganese on the limonite zone depicted by XRD (Figure
8C). Contrary, previous authors also suggested that nickel is present in an adsorbed or lattice bound state substituting iron in less crystalline goethite (Das et al., 1999). Nonetheless, following previous intense deliberations of manganese oxides (e.g, Roorda and Queneau, 1973), we suggest that nickel, cobalt, and manganese at Siruka have been precipitated together as oxidized concretions during laterization stages.

Subsequent to the co-precipitation event nickel was then leached out of earlier upper limonitic concretions, where it was first believed to have earlier concentrated with cobalt and manganese during the laterization and weathering earlier stages, and chiefly migrates to the saprolitic portion of the profiles at a later weathering stage. Major nickel enrichments in the saprolitic zone (average $1.33 \%$ ) occurred on fractures and voids commonly observed on the saprolitic columns. With respect to nickel contents, silicate horizons are richer than oxidized horizons in Siruka.

Cobalt is associated with manganese mineral phases particularly on the upper part of the profiles in Siruka, where liberated elements (e.g. nickel, silicon and magnesium) got depleted. Discrete concentration of cobalt is apparent on the limonitic portion of the profiles. According to Youngue-Fouateu et al. (2006), cobalt can significantly become enriched within the less crystalline manganese mineral hosts higher up in the profiles where remobilization and reprecipitations have led to the development of enriched zones and where nodules associated with well-crystalline manganese mineral of the asbolanelithiophorite group are observed. Petrographic analysis confirmed that nickel is associated with silica and magnesia, as lizardite and garnierite nickel ore at the saprolite zone along fractures and joints. The weathering-resistant chromium becomes residually enriched in the middle-limonitic zone while depletion of alkaline metals and silica is apparent. This could be attributable to prevalence of spinel on limonitic zone depicted on XRD (Figures 8C and 8D). Prevalence of chrome on zones where dissolution features observed in the profiles, as well as bulk chemical modification suggest that the 
chromites are slowly dissolved during pedogenesis (Garnier et al., 2008).

On the other hand, enrichment of gibbsite and manganese oxide mineral in the limonitic layer could mean repeated remobilizations of the residual material in which besides goethite, magnetite- maghemite transformation is likely, where magnetite more or less weathered to maghemite, this could also explain the high chromium content observed in the residue (Youngue-Fouateu et al., 2006). Aluminium is residually enriched in the granular limonitic zone as demonstrated in Figure 9. This behavior of aluminium is consistent with the low $\mathrm{pH}$ value of the limonite horizon. This explained the presence of gibbsite in the limonitic zone. Parallel resemblance of $\mathrm{Al}_{2} \mathrm{O}_{3}$ and $\mathrm{Fe}_{2} \mathrm{O}_{3}$ (Table 2) is attributed to the relative association and the occurrence of goethite, hematite and gibbsite in the upper portion of the profiles. Extensive XRD analysis on the granular limonitic portion of the profiles confirmed that goethite, hematite and kaolinite are the dominant minerals while gibbsite, asbolane and nontronite are sparsely distributed. Increasing $\mathrm{Al}_{2} \mathrm{O}_{3} / \mathrm{FeO}^{*}$ ratio from wet to dry portions of the profiles, i.e. from bottom to top of the profiles, signify active meteoric water involvement during the laterization process.

\section{Conclusion}

The lateritic weathering crust developed at Siruka, the southeastern part of Choiseul is broadly similar to saprolite nickel laterite deposit around the world. The mineralogical and geochemical process which affected the ultramafic bedrock and gave rise to the weathering crust in Siruka is characterized by obliteration and dissolution of bed rock followed by limonitization.

Chemical analyses' mass-balance calculations and quantitative correlation analyses suggest that progressive weathering of the parent rock is characterized by an enrichment of iron, cobalt, chromium, aluminium and manganese on the limonite zone, an incorporation of nickel at the boundary between the bedrock and the saprolite and in the lower part of the limonite, a depletion of magnesium and silicon. The Ni enrichment in Siruka is inferred to be attributed to percolation of surface solutions and the result of an ionic exchange reaction as: Mgserpentine $+\mathrm{Ni}^{2+}=$ Ni-rich serpentine $+\mathrm{Mg}^{2+}$.

With pronounced weathering, all relicts of bedrock and saprolite were obliterated and the limonite zone was formed. Therefore, we suggest that following the dissolution process is limonitization where iron oxides (goethite in particular) are dominant in the overlying limonite horizon at Siruka. In the upper part of the profile, leaching of $\mathrm{Mg}$ favored formation of nontronite. Nickel is a marker in the various horizons and appears in various mineral associations; generally with iron oxides (mainly as goethite but also with magnetite-maghemite relicts) defining the limonitic zone, unclear association with smectite (nontronite) and with serpentine in the saprolitic horizons.

Significant nickel enrichments are very partial in limonite zones but are chiefly developed in the saprolite zone indicating water movement through these zones downward to a very low water table, meaning much of the nickel in Siruka deposit percolated downwards and reprecipitated in the saprolite zones. Nickel content decreases upward the weathering profile since it is removed during the recrystallization of goethite and the leaching of manganese oxide phases. Crystallization of iron oxide in the form of goethite often has low capacity for nickel fixation. This could also allow easy capture of the metal by percolating down water from the limonitic horizon and redeposited in the saprolitic region at Siruka.

Conversely, nickel in Siruka has been substituting $\mathrm{Mg}$ in altered silicate during the earlier phases of the weathering, incorporated as concretions with other elements, leached from the limonite concretions, moves down the profile under the influence of gravitated percolating water, and finally redeposited in the saprolite zone, hosted by hydrous silicates. With this we classify the deposit as hydrous magnesium 'silicate type' deposit. 


\section{Acknowledgement}

This work was indebted to the Global Center of Excellence (G-COE), Kyushu University for its numerous supports in funding the research. Also grateful indeed for the technical support and field expertise provided by the SMM Solomon Ltd staffs, Solomon Islands.

\section{References}

Bonifacio, E., Zanini, E., Boero, V., FranchiniAngela, M. (1997) Pedogenesis in a soil catena on serpentine in north-western Italy. Geoderma, 75, 33- 51.

Bosio, N.J., Hurst, J.V., Smith, R.L. (1975) Nickelliferous nontronite, a $15 \AA$ garnierite, at Niquelandia, Goias Brazil. Clays Clay Miner., 23, 400-403.

Butt, C.R.M. and Sheppy, N.R. (1975) Geochemical exploration problems in Western Australia exemplified by Mt. Keith area. Elsevier, Amsterdam, 392-415.

Brand, N.W., Butt C.R.M., Elias, M. (1998) Nickel Laterites: Classification and features. AGSO Journal of Australian Geology \& Geophysics, 17 (4), 8188.

Braun, J.-J., Ndam Ngoupayou, J.-R., Viers, J., Dupre, B., Bedimo Bedimo, J.-P., Boeglin, J.-L., Robain, H., Nyeck, B., Freydier, R., Sigha Nkamdjou, L., Rouiller, J., Muller, J.-P. (2005) Present weathering rates in a humid tropical watershed: Nsimi, South Cameroon. Geochim. Cosmochim. Acta 69 (2): 357-387.

Colin, F., Nahon, D., Trescases, J.J., Melfi, A.J. (1990) Lateritic weathering of pyroxenites at Niquelandia, Goais, Brazil: The supergene behavior of nickel: Economic Geology, 85, 1010-1023.

Coleman, P.J. (1960) An introduction to the geology of the island of Choiseul in the Western Solomons 1957. British Solomon Islands Geological Record, $16-26$.

Das, S.K., Sahoo, R.K., Muralidhar, J., Nayak, B.K. (1999) Mineralogy and geochemistry of profiles through lateritic nickel deposits at Kansa, Sukinda, Orissa. Joural of Geoogical. Society India, 53, 649- 668.

Decarreau, A., Colin, F., Herbillon, A., Manceau, A., Nahon, D., Paquet, H., Trauth-Badaud, D., Trescases, J.J. (1987) Domain segregation in NIFe-Mg-Smectites. Clay Clays Miner. 35, 1-10.

Elias, M., Donaldson, M.J., Giorgetta, N.E. (1981) Geology, mineralogy, and chemistry of lateritic nickel-cobalt deposits near Kalgoorlie, Western Australia. Economic Geology, 76 (6), 1775-1783.

Garnier, J., Quantin, C., Martins, E.S., Becquer, T. (2006) Solid speciation and availability of chromium in ultramafic soils from Niquelandia, Brazil. Journal of Geochemical Exploration. 88, 206-209.

Garnier, J., Quantin, C., Guimarães, E., Becquer, T. (2008). Can chromite weathering be a source of $\mathrm{Cr}$ in soils? Mineralogy Magazine, 72, 49-53.

Golightly, J.P. (1981). Nickeliferous laterite deposits: Economic Geology 75th Anniversary volume: 710-735.

Gleeson, S.A., Butt, C.R., Wlias, M. (2003) Nickel laterites: a review. SEG Newsletter, Society of Economic Geology, 54. Available from www.segweb.org.

Orquidea, C., Federico, G., Ianeya, H., Jeannette, M., Edgardo, D. (2008) Cobalt and nickel recoveries from laterite tailings by organic and inorganic bioacids. Hydrometallurgy, 94, 18-22.

Kuck, P.H. (1992) Nickel, Bureau of Mines/Minerals year book, 1, 863-894.

Kurtz, A.C., Derry, L.A., Chadwick, O.A., Alfano, M.J. (2000). Refractory element mobility in volcanic soil. Geology, 28 (8): 683-686.

Llorca, S.M. (1993) Mettalogeny of supergene cobalt mineralization, New Caledonia. Australian Journal of Earth Sciences, 40, 377-385.

Llorca, S., and Monchoux, P. (1991) Supergene cobalt minerals from New Caledonia. Can. Mineral, 29, 149-161.

Marker, A., Friedrich, G., Carvalho, A., Melfi, A. (1991). Control of the distribution of Mn, Co, Zn, $\mathrm{Zr}$, Ti and REEs during the evolution of lateritic covers above ultramafic complexes. Journal of Geochemical Exploration, 40, 361-383.

Moroni. M., Girardi V.A.V., Ferrario A. (2001). The Serra Pelada Au-PGE deposit, Serra dos Carajas (Para state, Brazil): geological and geochemical indications for a composite mineralising process. Mineralium Deposita, 36, 768-785.

Mungall, J.E. and Martin, R.F. (1994) Severe leaching of trachyte glass without devitrification. , Terceira, Azores. Geochimica Cosmochimica Acta, 58: 75-83.

Nahon, D., Paquet, H., Delvigne, J. (1982) Lateritic weathering of ultramafic rocks and the concentration of nickel in western Ivory Coast. Economic Geology, 77, 1159-1175.

Nahon, D., and Merino, E. (1997) Pseudomorphic replacement in tropical weathering: evidence, geochemical consequences and kinematicrheological origin. American Journal of Sciences. 297: 393-417.

Ndjigui, P-D., Bilong, P., Bitom, D., and Dia, A. (2008) Mobilization and redistribution of major and trace elements in two weathering profiles developed on serpentinites in the Lomié ultra- 
mafic complex, South-East Cameroon. Journal of African Earth Sciences. 50: 305-328.

Nesbitt H. W., and Wilson R.E. (1992) Recent chemical weathering of basalts. American Journal of Sciences, 292: 740-777.

Ogura, Y., Murata, K., Iwai, A. (1986) Relationship between chemical composition and particle-size distribution of ores in the profile of nickeliferous laterite deposits of the Rio Tuba Mine, Philippines. Chemical Geology, 60, 259.

Pelletier, B., (1996). Serpentines in nickel silicate ores from New Caledonia, in Grimsey, E.J., and Neuss, I. (eds). Nickel '96, Australasian Institute of Mining and Metallurgy, Melbourne, Publication Series 6/9, 197-205.

Petterson, M.G., Babbs, T., Neal, C. R., Mahoney, J. J., Saunders, A. D., Duncan, R. A., Tolia, D., Magu, R., Qopoto, C., Mahoa, H. and Natogga, D. (1999) Geological-tectonic framework of Solomon Islands, SW Pacific: crustal accretion and growth within an intra-oceanic setting. Tectonophysics, 301(1-2), 3560.

Purvis, J.G. and Kemp, G.J. (1975) Final report on reconnaissance permits R33, R35, R36 Choiseul.
Unpublished report Conzinc Riotinto Australia Exploration pty Ltd (CRA) (open-file, Geology Division, Mining Natural Resources, Honiara, Solomon Islands).

Ridgway, J. and Coulson, F.I.E. (1987) The geology of Choiseul and the Shortland Islands, Solomon Islands. British Geological Survey, HMSO, London, 134 (+ maps).

Roorda, H.J., Queneau, P.E. (1973) Recovery of nickel and cobalt from limonites by aqueous chloriation in sea water. Trans. IMM C, 82, 79-87.

Thompson, R.B. (1960) The geology of ultrabasic rocks of the British Solomon Islands. PhD thesis, University of Sydney.

Wells, M.A. (2003) Murrin Murrin nickel laterite deposit. Western Australia. CRC LEME, p. 3.

Youngue-Fouateu, R., Ghogomu, R.T., Penaye J., Ekodeck G.E., Stendal H., Colin F. (2006) Nickel and cobalt distribution in laterites of the Lomié region, south-east Cameroon. Journal of African Earth Sciences, 45, 33-47. 